\title{
Sources and preservation of organic matter in soils of the wetlands in the Liaohe (Liao River) Delta, North China
}

\author{
Tian Lin ${ }^{\mathrm{a}, \mathrm{b}, *}$, Siyuan $\mathrm{Ye}^{\mathrm{c}}$, Chuanliang Ma ${ }^{\mathrm{b}}$, Xigui Ding ${ }^{\mathrm{c}}$, Hans Brix ${ }^{\mathrm{d}}$, Hongming Yuan ${ }^{\mathrm{c}}$, Yingjun Chen ${ }^{\mathrm{e}}$, \\ Zhigang Guo ${ }^{\mathrm{b}}$
}

a State Key Laboratory of Environmental Geochemistry, Institute of Geochemistry, Chinese Academy of Sciences, Guiyang 550002, China

${ }^{\mathrm{b}}$ Department of Environmental Science and Engineering, Fudan University, Shanghai 200433, China

${ }^{\mathrm{c}}$ Key Laboratory of Marine Hydrocarbon Resources and Environmental Geology, Ministry of Land and Resources of China, Qingdao 266071, China

${ }^{\mathrm{d}}$ Department of Bioscience, Aarhus University, Denmark

${ }^{\mathrm{e}}$ Key Laboratory of Coastal Zone Environmental Processes, Yantai Institute of Coastal Zone Research, Chinese Academy of Sciences, Yantai 264003, China

\section{A R T I C L E I N F O}

\section{Keywords:}

Organic matter

Sources and preservation

Biomarkers

Soils

Wetlands

Liao River Delta

\begin{abstract}
A B S T R A C T
Total organic carbon, total nitrogen, $\delta^{13} \mathrm{C}_{\mathrm{org}}, \delta^{15} \mathrm{~N}$, and aliphatic and polyaromatic hydrocarbons of fiftyfive soil samples collected from the coastal wetlands of the Liaohe Delta were measured, in order to determine the sources and possible preservation of organic matter (OM). The $\delta^{15} \mathrm{~N}$ and $\delta^{13} \mathrm{C}_{\text {org }}$ values in the samples ranged from $3.0 \%$ to $9.4 \%$ and from $-30.4 \%$ to $-20.3 \%$, respectively, implying that the $\mathrm{OM}$ in the soils is predominantly derived from $\mathrm{C}_{3}$ plant. The long-chain $n$-alkanes had a strong odd-over-even carbon number predominance, suggesting a significant contribution from waxes of higher plants. The ubiquitous presence of unresolved complex mixture, alkylated polycylic aromatic hydrocarbons and typical biomarkers of petroleum hydrocarbons (pristane, phytane, hopanes and steranes) indicates that there is a contribution of petroleum hydrocarbons to the organic carbon pool in the wetland soils. P. australis-vegetated wetlands have strong potentials for the preservation of organic carbon in the wetlands.
\end{abstract}

(c) 2013 Elsevier Ltd. All rights reserved.

\section{Introduction}

Wetlands are well known for their high productivity and their potential to sequester carbon dioxide from the atmosphere. The decomposition rate of organic matter $(\mathrm{OM})$ in wetland soils is generally slow because of the anoxic wet conditions. It is estimated that $20-30 \%$ of the Earth's soil pool of 2500 Pg of carbon is stored in wetlands (Roulet, 2000; Bridgham et al., 2006), although wetlands comprise only about $5-8 \%$ of the terrestrial land surface (Mitsch and Gosselink, 2007). Wetlands are also a source of greenhouse gas emissions, especially methane (Mitsch et al., 2012). Thus, wetland ecosystems play a significant role in the global carbon cycle and climate change.

The coastal wetlands of the Liaohe (Liao River) Delta (LRD) are located in the northern Liaodong Bay of the Bohai Sea, North China (Fig. 1), and cover a geographic area of approximately $3150 \mathrm{~km}^{2}$. The common reed (Phragmites australis (Cav.) Trin. ex Steud.) is

\footnotetext{
* Corresponding author at: State Key Laboratory of Environmental Geochemistry, Institute of Geochemistry, Chinese Academy of Sciences, Guiyang 550002, China. Tel./fax: +86 8515895239.

E-mail address: lintian@gyig.ac.cn (T. Lin).
}

the dominant plant species in the delta wetlands, and the LRD reed stands are the largest in Asia and the second largest one in the world. The LRD is the leading economic center of Northeast China with an extensive industry based on the abundant oil and natural gas resources. Furthermore, the delta provides excellent conditions for the production of rice and commercial aquaculture systems. Due to the excessive population growth and the increasing demands for cultivable lands, more and more of the delta wetlands are being reclaimed. Large amounts of heavy oil-polluted process water from oil extraction in the Liaohe Oilfield, the third largest in China, are discharged into the Liao River in the Delta (Ji et al., 2002). Both the land reclamation for agriculture and aquaculture, and the oil extraction is likely to affect the production, transport and burial of OM in the LRD wetlands.

One approach to understand sources and fate mechanisms of OM accumulated in sediments and soils is to utilize a molecular organic geochemical method, where $n$-alkanes, pristane $(\operatorname{Pr})$, phytane $(\mathrm{Ph})$, the unresolved complex mixture (UCM), alkylated polycyclic aromatic hydrocarbons (PAHs), hopane and sterane are used for the source identification of the OM (Yunker et al., 2002b; Kimbrough and Dickhut, 2006; Wang et al., 2006; Hu et al., 2009; Tolosa et al., 2009; Wang et al., 2011). These biomarkers, combined with total organic carbon (TOC), total nitrogen (TN), $\delta^{13} \mathrm{C}_{\text {org }}$ and $\delta^{15} \mathrm{~N}$ in 

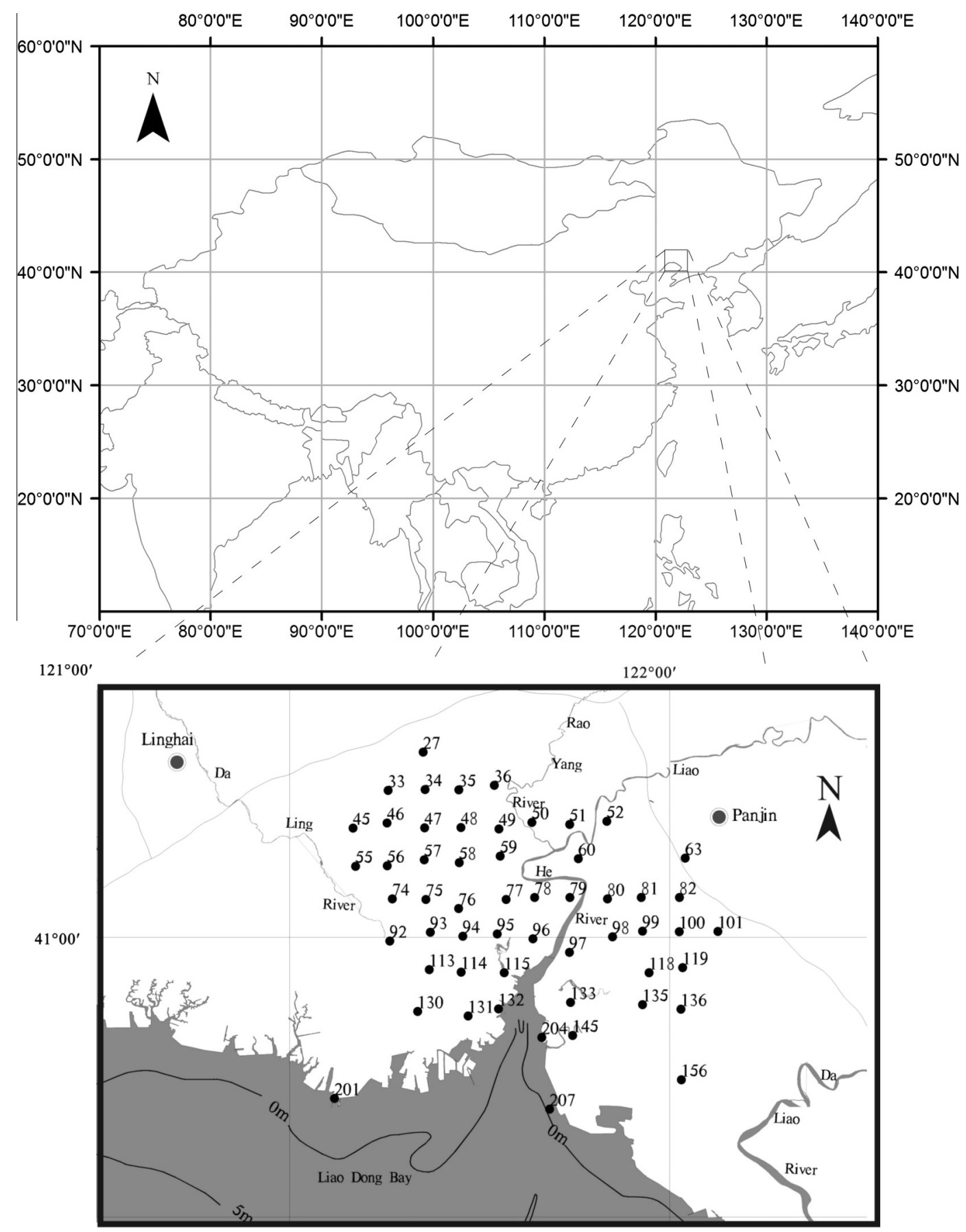

Fig. 1. Study area and locations of sampling sites.

the soils can provide robust and powerful proxies for the distinguishing of the OM contributions from natural or anthropogenic sources (Wang et al., 2003; Tanner et al., 2010). Several studies have been conducted mainly on the environmental assessments of contaminated soils and sediments in the LRD and Liao River Estuary (Guo et al., 2007; Xu et al., 2009; Wang et al., 2010). However, to our knowledge, the biogeochemistry of the soil OM in the wetlands from LRD has not been studied. The main objectives of the present study were therefore to map and identify the sources of the OM in the LRD using organic biomarkers, in order to increase our understanding of the role of the LRD wetlands, and their management for OM preservation and carbon sequestration.

\section{Materials and methods}

\subsection{Sample collection and preparation}

Fifty-five soil samples were collected from the LRD in August 2011 (Fig. 1). The sample locations were distributed across the LRD and represented four dominant vegetation types in the delta: common reed ( $P$. australis (Cav.) Trin. ex Steud., $n=24$ ), sea blite (Suaeda salsa Pall., $n=4$ ), rice (Oryza sativa, $n=20$ ) and maize (Zea mays, $n=7)$. Surface soils $(0-5 \mathrm{~cm}$ depth), the upper layers of plant roots, were taken with a stainless steel soil auger after removing the uppermost plant cover. Three soils were collected 
within $100 \mathrm{~m} \times 100 \mathrm{~m}$ grid square and combined to make one sample. The samples were packed in aluminum foil. In laboratory, removed wood, gravel and other materials, the samples were ground and then sieved through a 100-mesh stainless sieve for organic analysis.

\subsection{Analysis of grain size and bulk parameter analysis}

For texture analysis, about $1 \mathrm{~g}$ of unground sample was treated with $30 \%(\mathrm{v} / \mathrm{v}) \mathrm{H}_{2} \mathrm{O}_{2}$ to oxidize the OM. The samples were then dispersed and homogenized using ultra-sonic vibration for $30 \mathrm{~s}$ prior to instrumental analysis. The grain size distribution was determined using a Laser Particle Size Analyzer (Mastersizer 2000, Malven Instruments Ltd., UK). The relative error of the duplicate samples was less than $3 \%(n=6)$.

For the bulk chemical analysis, samples were decalcified using $4 \mathrm{M} \mathrm{HCl}$ and subsequently rinsed with deionized water before drying overnight at $60^{\circ} \mathrm{C}$. The carbonate-free samples were then analyzed for TOC and TN in duplicate using a Vario EL-III Elemental Analyzer, and the average values were reported. The replicate analysis of one sample gave a precision of $\pm 0.02 \mathrm{wt}$.\% for TOC and TN. Carbon and nitrogen isotope analyses were conducted on a Thermo Finnigan Delta Plus XL mass spectrometer connected with a Flash EA 1112 elemental analyzer via a Finnigan MAT ConFlo III interface. $\delta^{13} \mathrm{C}_{\mathrm{org}}$ and $\delta^{15} \mathrm{~N}$ are reported as per mil relative to the Vienna Pee Dee Belemnite (VPDB) standard and air, respectively. The instrument analytical precisions for $\delta^{13} \mathrm{C}_{\mathrm{org}}$ and $\delta^{15} \mathrm{~N}$ were $0.1 \%$ and $0.2 \%$, respectively.

\subsection{Hydrocarbon analysis}

The laboratory analysis was performed at the Key Laboratory of Coastal Zone Environmental Processes, Yantai Institute of Coastal Zone Research, Chinese Academy of Sciences, China. The procedures for the extraction and fractionation of the hydrocarbons followed that described by $\mathrm{Hu}$ et al. (2009). Briefly, about $10 \mathrm{~g}$ soil sample was spiked with a mixture of recovery standards of three deuterated PAHs (phenanthrene- $\mathrm{d}_{10}$, chrysene- $\mathrm{d}_{12}$, and perylene$\left.\mathrm{d}_{12}\right)$ and two deuterated $n$-alkanes $\left(\mathrm{C}_{16}-\mathrm{d}_{50}, \mathrm{C}_{24}-\mathrm{d}_{50}\right)$. The sample was then extracted with dichloromethane in a Soxhlet apparatus for $48 \mathrm{~h}$. Activated copper was added to remove the sulfur in sample. The extracts were concentrated and solvent-exchanged to hexane using a rotary evaporator. Concentrated extracts were cleaned and fractionated on an $8 \mathrm{~mm}$ i.d. alumina/silica column packed, from the bottom to top, with neutral alumina $(3 \mathrm{~cm}, 3 \%$ deactivated), neutral silica gel ( $3 \mathrm{~cm}, 3 \%$ deactivated), and anhydrous sodium sulfate $(1 \mathrm{~cm})$. The fraction was eluted with $50 \mathrm{~mL}$ of dichloromethane/n-hexane (1:1), and solvent-exchanged to hexane and concentrated to $0.5 \mathrm{~mL}$ under a gentle nitrogen stream.

The fractions (including $n$-alkanes, UCM, Ph, Pr, alkylated PAHs, hopanes and steranes) were determined using an Agilent 6890 Series Gas Chromatography/Series 5975 Mass Spectrometer (GC/MS) in the full scan mode. Chromatographic separation was achieved by a DB-5MS capillary column ( $30 \mathrm{~m}$ long $\times 0.25 \mathrm{~mm}$ i.d., $0.25 \mu \mathrm{m}$ film thickness, J\&W Scientific, Folsom, CA) with a splitless injector and mass spectrometer detector. Helium was used as the carrier gas $\left(1.0 \mathrm{ml} \mathrm{min}^{-1}\right)$. Samples were injected in the splitless mode at an injector temperature of $280^{\circ} \mathrm{C}$. Oven temperature was programmed from $60^{\circ} \mathrm{C}$ to $180^{\circ} \mathrm{C}(1 \mathrm{~min}$ hold $)$, at a rate of $8{ }^{\circ} \mathrm{C} \mathrm{min}-1$, and from $180{ }^{\circ} \mathrm{C}$ to $300{ }^{\circ} \mathrm{C}$ ( 2 min hold $)$, at a rate of $3{ }^{\circ} \mathrm{C} \min ^{-1}$. The mass spectrum was operated in the electron ionization (EI) mode $(70 \mathrm{eV})$, and the mass scanning ranged between $\mathrm{m} / \mathrm{z} 50$ and $500 \mathrm{amu}$.

The concentrations of individual $n$-alkane were determined by using authentic standards of $n$-alkanes $\left(C_{16}, C_{20}, C_{24}, C_{28}\right.$, and $\left.C_{32}\right)$. Other $n$-alkanes $\left(C_{10}-C_{35}\right), P h$ and Pr were identified based on the retention times and mass spectra of target compounds against the authentic standards. The concentrations of others were quantified relative to authentic standards. Relative response factors for the $n$-alkanes which were not included in the standard compounds were calculated by linear interpolation. The UCM was calculated using the mean response factors of $n$-alkanes with corresponding carbon chain.

Petroleum biomarkers (hopanes and steranes) were identified by monitoring the respective typical ions: $m / z 191$ for hopanes, and $m / z 217$ and $m / z 218$ for steranes (Zaghden et al., 2007). Similarly, alkylated PAHs were measured based on the retention times against the authentic standards (16 US EPA PAHs) and typical ions as shown in Mai et al. (2001). The concentrations of individual alkylated-PAHs were quantified base on the response area comparing with its parent PAH. The average recovery of the standards spiked into each sample prior to analysis was $90 \pm 11 \%$ for phenanthrene- $d_{10}, 91 \pm 8 \%$ for chrysene- $d_{12}$, and $96 \pm 11 \%$ for perylened$\mathrm{d}_{12}$.

\section{Results and discussion}

\subsection{Geochemistry of bulk organic matter}

Most wetland soil samples in the LRD were classified as clayey-silt and sandy-silt. The TOC contents in the samples ranged broadly from $0.56 \%$ to $23 \%$ with a mean of $5.4 \pm 5.0 \%$ (Table 1 ). Overall, the TOC contents of more than three quarters of the samples were below $10 \%$. The sites with TOC contents $>10 \%$ were all located in the Phragmites-covered areas, namely sites number 35 (15\%), 36 (23\%), 49 (12\%), 59 (19\%), 76 (12\%), 77 (17\%) and 78 (18\%). Even after removing these sites with very higher TOC contents, the Phragmites-covered soils still had higher TOC contents $(5.5 \pm 1.0 \%)$ than those from other areas. The wetland areas that had been reclaimed for agricultural use had significantly lower TOC contents, namely $1.9 \pm 1.0 \%$ and $2.7 \pm 0.9 \%$ for Zea- and Ory$z a$-covered soils, respectively, whereas the TOC contents in the Suaeda-covered soils $(4.3 \pm 2.3 \%)$ were in-between the agricultural soils and the Phragmites-covered soils (Fig. 2). In concert with the pattern for TOC, high TN contents were found at sites number 35 (0.83\%), 36 (1.12\%), 49 (0.68\%), 59 (0.95\%), 76 (0.57\%), 77 (0.86\%) and $78(1.01 \%)$. The TN contents at these sites were significantly higher than the TN contents at the other sites which were in the range of $0.02-0.35 \%(0.13 \pm 0.08 \%, n=48)$ (Fig. 3$)$. There was a significant positive correlation $\left(R^{2}=0.96, n=55\right)$ between TOC and $\mathrm{TN}$ in the soil samples. The TOC/TN ratios ranged from 17 to 43 with an average of $28 \pm 7$. Nonvascular aquatic plants have been reported to have a relatively low TOC/TN ratio, typically between 4 and 10, whereas vascular plants have TOC/TN ratios higher than 20 (Lawrence, 1994; Meyers and Ishiwatari, 1993). Therefore, the high TOC/TN ratios found in the delta wetland soils indicate that the OM in the LRD predominantly originates from higher plants.

The stable carbon/nitrogen isotopic compositions $\left(\delta^{13} \mathrm{C}_{\mathrm{org}}\right.$ and $\delta^{15} \mathrm{~N}$ ) can be used to distinguish the potential sources of the OM in soils. For example, $\delta^{15} \mathrm{~N}$ values ranging from $-2 \%$ to $4 \%$ are typical for $\mathrm{N}$ in commercial fertilizers, 3-8\% are for $\mathrm{N}$ from plant residues, and $10-20 \%$ are for nitrate- $\mathrm{N}$ from human and animal waste (Aravena et al., 1993). In this study, the $\delta^{15} \mathrm{~N}$ values in the samples were in the range between $3.0 \%$ and $9.4 \%$, which also suggesting that higher plants are a dominant source for the soil OM. The $\delta^{13} \mathrm{C}_{\text {org }}$ values in the samples ranged from $-30.4 \%$ o to $-20.3 \%$ o $(-25.4 \pm 2.0 \%$ in average). Higher plants with $\mathrm{C} 3$ photosynthesis, like $P$. australis, are reported to result in $\delta^{13} \mathrm{C}_{\mathrm{org}}$ values between $-23 \%$ to $-34 \%$ (Tanner et al., 2010). Hence, the $\delta^{13} C_{\text {org }}$ values found in the LRD are consistent with the fact that $P$. australis is 
Table 1

Concentrations $(\mu \mathrm{g} / \mathrm{g})$ of selected lipids, TOC (\%) and TN (\%) and compositions of $\delta{ }^{15} \mathrm{~N}(\%)$ and $\delta{ }^{13} \mathrm{C}_{\text {org }}(\%)$ in soils from the Wetlands of Liaohe Delta.

\begin{tabular}{|c|c|c|c|c|c|c|c|c|c|}
\hline & $\mathrm{TN}$ & TOC & $\delta^{15} \mathrm{~N}$ & $\delta^{13} \mathrm{C}_{\text {org }}$ & n-Alkanes & $\operatorname{Pr}^{\mathrm{a}}$ & $\mathrm{Ph}^{\mathrm{a}}$ & UCM & Alkylated-PAHs \\
\hline 27 & 0.07 & 2.42 & 8.1 & -24.4 & 2.45 & 5.58 & 14.65 & 1.40 & 0.18 \\
\hline 33 & 0.05 & 1.69 & 4.4 & -20.3 & 6.36 & 6.75 & 11.93 & 3.87 & 0.14 \\
\hline 34 & 0.07 & 2.75 & 6.6 & -22.5 & 4.23 & 3.96 & 11.05 & 0.49 & 0.06 \\
\hline 35 & 0.83 & 15.60 & 4.9 & -27.1 & 35.68 & 24.28 & 26.33 & 3.83 & 0.84 \\
\hline 36 & 1.13 & 23.03 & 5.5 & -27.2 & 48.11 & 32.16 & 76.86 & 6.71 & 1.41 \\
\hline 45 & 0.08 & 1.60 & 6.6 & -21.6 & 4.03 & 5.54 & 9.49 & 0.35 & 0.07 \\
\hline 46 & 0.03 & 0.56 & 5.8 & -23.1 & 5.22 & 34.13 & 65.93 & 1.08 & 0.13 \\
\hline 47 & 0.09 & 1.64 & 8.6 & -21.4 & 5.74 & 5.85 & 18.78 & 3.37 & 0.16 \\
\hline 48 & 0.05 & 1.07 & 5.9 & -23.6 & 3.33 & 3.28 & 18.21 & 1.23 & 0.11 \\
\hline 49 & 0.69 & 12.10 & 4.3 & -28.2 & 70.41 & 18.68 & 43.44 & 11.61 & 0.89 \\
\hline 50 & 0.27 & 6.98 & 6.2 & -27.0 & 13.04 & 9.31 & 17.81 & 2.68 & 0.44 \\
\hline 51 & 0.11 & 3.10 & 7.7 & -26.8 & 8.24 & 4.58 & 12.42 & 2.06 & 0.13 \\
\hline 52 & 0.14 & 4.80 & 6.4 & -25.0 & 6.33 & 9.21 & 48.91 & 3.17 & 0.20 \\
\hline 55 & 0.23 & 3.90 & 9.4 & -22.9 & 23.68 & 41.99 & 64.20 & 6.88 & 0.62 \\
\hline 56 & 0.07 & 2.32 & 5.1 & -25.5 & 10.96 & 8.80 & 15.07 & 2.12 & 0.32 \\
\hline 57 & 0.26 & 4.69 & 3.0 & -26.0 & 12.58 & 17.55 & 33.70 & 5.98 & 0.35 \\
\hline 58 & 0.22 & 5.44 & 4.9 & -25.5 & 8.85 & 5.66 & 10.71 & 1.97 & 0.18 \\
\hline 59 & 0.96 & 19.09 & 5.0 & -28.0 & 85.76 & 57.09 & 100.37 & 16.34 & 1.58 \\
\hline 60 & 0.13 & 4.78 & 7.2 & -26.5 & 11.14 & 11.61 & 28.02 & 2.52 & 0.18 \\
\hline 63 & 0.09 & 2.39 & 6.9 & -25.4 & 25.45 & 146.69 & 157.74 & 53.81 & 0.31 \\
\hline 74 & 0.11 & 2.63 & 6.2 & -26.5 & 6.72 & 7.85 & 17.58 & 1.65 & 0.30 \\
\hline 75 & 0.26 & 6.22 & 4.1 & -27.7 & 7.18 & 11.16 & 13.34 & 2.55 & 0.29 \\
\hline 76 & 0.57 & 12.08 & 3.8 & -27.9 & 20.24 & 51.54 & 62.55 & 11.44 & 1.64 \\
\hline 77 & 0.86 & 17.36 & 5.7 & -28.2 & 74.04 & 346.87 & 371.81 & 17.25 & 1.98 \\
\hline 78 & 1.01 & 17.99 & 6.3 & -29.0 & 65.54 & 354.70 & 498.31 & 15.55 & 4.99 \\
\hline 79 & 0.22 & 6.02 & 7.1 & -26.0 & 12.13 & 26.88 & 48.11 & 4.35 & 0.41 \\
\hline 80 & 0.07 & 2.67 & 7.6 & -25.1 & 5.75 & 5.82 & 13.36 & 2.14 & 0.13 \\
\hline 81 & 0.08 & 3.25 & 7.2 & -26.2 & 5.57 & 3.82 & 12.77 & 1.41 & 0.14 \\
\hline 82 & 0.09 & 2.89 & 6.8 & -26.0 & 9.36 & 7.49 & 14.86 & 2.84 & 0.20 \\
\hline 92 & 0.06 & 1.43 & 3.9 & -21.4 & 7.37 & 7.59 & 7.43 & 2.53 & 0.16 \\
\hline 93 & 0.26 & 6.98 & 5.5 & -25.6 & 13.46 & 55.81 & 53.42 & 4.92 & 0.82 \\
\hline 94 & 0.25 & 7.10 & 4.9 & -27.0 & 10.65 & 102.09 & 235.93 & 19.13 & 1.81 \\
\hline 95 & 0.35 & 8.75 & 5.0 & -27.2 & 20.14 & 12.49 & 20.54 & 4.38 & 0.31 \\
\hline 96 & 0.26 & 6.39 & 5.2 & -27.4 & 21.18 & 8.37 & 15.41 & 2.70 & 0.25 \\
\hline 97 & 0.11 & 4.40 & 7.6 & -24.5 & 10.09 & 6.15 & 14.34 & 1.48 & 0.16 \\
\hline 98 & 0.02 & 0.73 & 6.3 & -24.6 & 1.44 & 2.90 & 5.22 & 0.15 & 0.05 \\
\hline 99 & 0.07 & 2.13 & 7.1 & -25.9 & 3.96 & 3.38 & 6.39 & 0.57 & 0.07 \\
\hline 100 & 0.09 & 2.41 & 7.4 & -26.3 & 5.11 & 6.47 & 15.56 & 1.72 & 0.13 \\
\hline 101 & 0.11 & 3.10 & 6.8 & -23.6 & 7.83 & 23.51 & 27.37 & 3.94 & 0.48 \\
\hline 113 & 0.27 & 7.57 & 3.1 & -25.5 & 12.56 & 21.70 & 24.10 & 2.64 & 0.52 \\
\hline 114 & 0.31 & 8.41 & 5.2 & -26.3 & 17.73 & 22.17 & 23.07 & 2.53 & 0.78 \\
\hline 115 & 0.08 & 2.36 & 6.9 & -25.0 & 4.92 & 9.13 & 14.73 & 1.45 & 0.18 \\
\hline 118 & 0.06 & 2.30 & 5.4 & -24.7 & 6.22 & 2.78 & 8.08 & 1.23 & 0.07 \\
\hline 119 & 0.11 & 2.87 & 7.5 & -25.4 & 11.67 & 5.25 & 23.82 & 1.98 & 0.32 \\
\hline 130 & 0.18 & 6.52 & 5.2 & -25.6 & 12.64 & 28.58 & 33.23 & 3.11 & 0.75 \\
\hline 131 & 0.09 & 3.36 & 6.0 & -26.7 & 7.02 & 10.47 & 12.61 & 1.84 & 0.19 \\
\hline 132 & 0.06 & 2.63 & 7.1 & -24.3 & 5.68 & 28.22 & 29.01 & 4.60 & 0.16 \\
\hline 133 & 0.22 & 5.66 & 5.5 & -25.8 & 9.84 & 7.72 & 8.54 & 1.45 & 0.20 \\
\hline 135 & 0.11 & 2.83 & 8.2 & -25.9 & 6.23 & 3.15 & 10.85 & 1.90 & 0.11 \\
\hline 136 & 0.09 & 2.81 & 8.3 & -25.1 & 4.28 & 6.14 & 10.74 & 1.43 & 0.16 \\
\hline 145 & 0.04 & 1.81 & 4.8 & -25.0 & 3.98 & 36.19 & 64.31 & 1.37 & 0.17 \\
\hline 156 & 0.06 & 1.58 & 5.7 & -23.0 & 2.43 & 3.80 & 8.87 & 0.74 & 0.07 \\
\hline 201 & 0.07 & 2.29 & 7.8 & -21.9 & 12.92 & 27.95 & 28.35 & 2.36 & 0.46 \\
\hline 204 & 0.08 & 3.67 & 8.4 & -23.6 & 6.38 & 13.69 & 15.98 & 2.26 & 0.27 \\
\hline 207 & 0.09 & 3.64 & 8.3 & -30.4 & 6.77 & 18.72 & 20.11 & 1.88 & 0.28 \\
\hline
\end{tabular}

a The concentration of $\mathrm{Pr}$ and $\mathrm{Ph}: \mathrm{ng} / \mathrm{g}$.

the dominant plant species in the delta wetlands, and contribute the most to the soil OM.

\subsection{Aliphatic hydrocarbons}

The total concentrations of $n$-alkanes $\left(C_{10}-C_{35}\right)$ in the soils in the LRD ranged from 1.4 to $85.7 \mu \mathrm{g} / \mathrm{g}$ with an average of $15.1 \pm 18.7 \mu \mathrm{g} / \mathrm{g}$. Sites number $35,36,49,59,77$ and 78 had the highest levels $(>30 \mu \mathrm{g} / \mathrm{g}$ ) for the total $n$-alkane concentrations (Table 1 ). The $n$-alkane homologues were characterized by a single modal molecular distribution, generally with $C_{29}$ or $C_{31}$ as the maximum homologue (Fig. 4). Generally, the sources of the short-chain homologues of $n$-alkane $\left(n \leqslant C_{20}\right)$ are from multiple sources, including phytoplankton, photosynthetic bacteria and higher aqua- tic plants (Meyers and Ishiwatari, 1993; Meyers, 1997), whereas the long-chain homologues $\left(\geqslant C_{21}\right)$ are believed to be largely derived from waxes of higher plants (Logan and Eglinton, 1994). The carbon predominance index (CPI) for the $n$-alkanes $\left(\mathrm{C}_{21}-\mathrm{C}_{34}\right)$ ranged from 1.5 to $9.7(5.8 \pm 1.7)$ in the LRD, which also indicates that the long-chain $n$-alkanes were mainly derived from waxes of higher plants, such as P. australis (Schefuß et al., 2003; Wang et al., 2003). One of the commonly used proxies to evaluate the relative importance of terrigenous and aquatic planktonic/bacterial sources was derived from a study of Lake Erie by Bourbonniere and Meyers (1996). They defined the ratio of the long-chain $n$-alkanes to the short-chain ones $(L / S)$ as terrigenous versus planktonic/bacterial contribution of the $n$-alkanes. In this study, the $L / S$ ratios are higher than 1 in all sediments and higher than 7 in most 


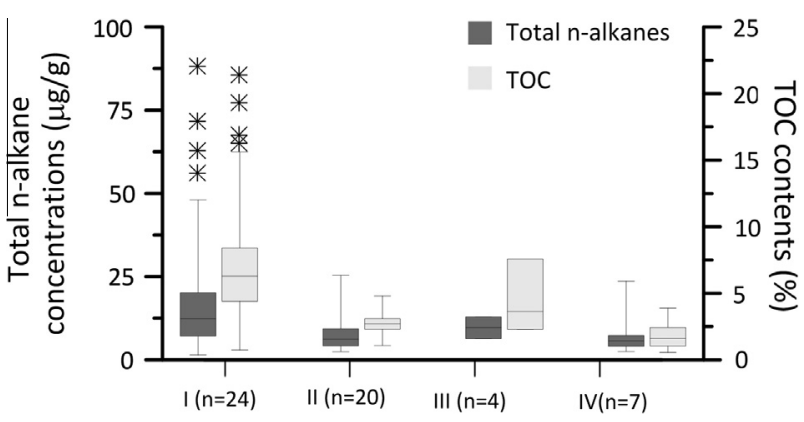

Fig. 2. Box-whisker plots of concentrations of TOC and total $n$-alkanes in soils from different kinds of vegetation-covered area (I: Phragmites australis (Cav.) Trin. ex Steud.; II: Oryza sativa; III: Suaeda salsa Pall.; IV: Zea mays)).
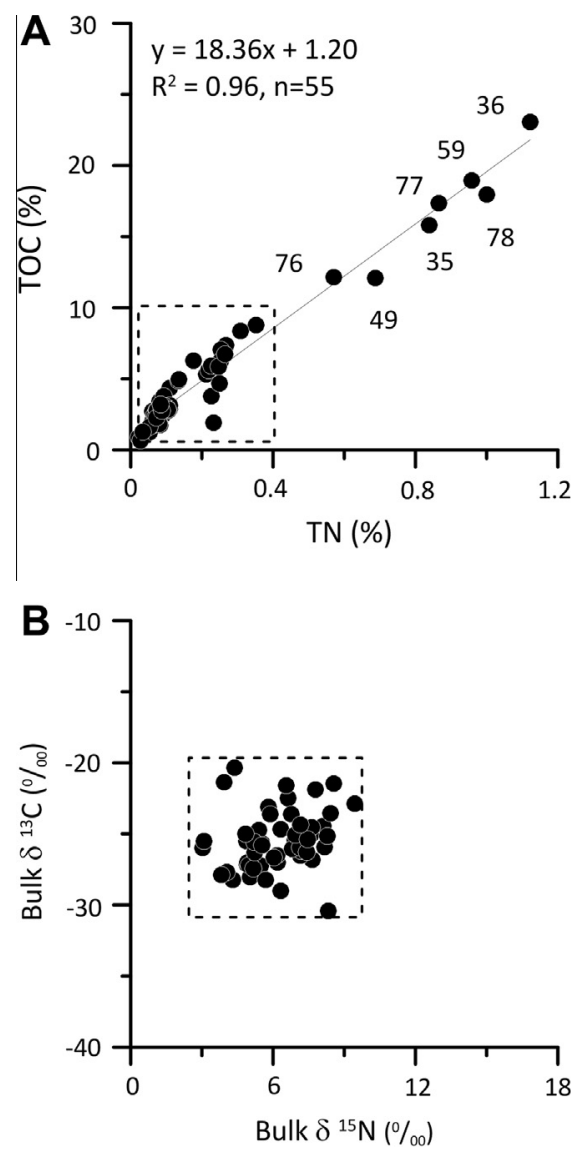

Fig. 3. Plots of TN versus TOC (A), and $\delta^{15} \mathrm{~N}$ versus $\delta^{13} \mathrm{C}(\mathrm{B})$.

of the samples ( $>75 \%$ ), which might be attributed to a dominant source of higher plants for the OM in the soils. This is in agreement with the results from the TOC/TN ratios as discussed above.

The two isoprenoid hydrocarbons, $\mathrm{Pr}$ and $\mathrm{Ph}$, are commonly present in crude oils, zooplankton, algae and bacteria. A high concentration of a single $\mathrm{Pr}$ indicates a biogenic origin, while $\mathrm{Ph}$ is practically absent in uncontaminated soils/sediments (Medeiros and Bicego, 2004a; Medeiros and Bicego, 2004b). High concentrations of Ph (>100 ng/g) were found at sites number 59, 63, 77, 78 and 94 in this study, indicating a significant contamination with petroleum hydrocarbon at these sites. Short-chain even number n-alkanes (such as $\mathrm{C}_{16}$ and $\mathrm{C}_{18}$ ) would be degraded prior to significant alternation of the counterparts, thus the values of $\mathrm{C}_{18} / \mathrm{Ph}$ ratios for moderate to severe biodegradation of petroleum-derived
OM may be lower than 1 (Medeiros et al., 2005; Mille et al., 2007). In the present study, however, the $C_{18} / \mathrm{Ph}$ ratios are much higher than 1 , even though in those sites $(59,63,77,78$ and 94) it had high $\mathrm{Ph}$ concentrations. This suggests that there was possibly a fresh input of crude oil at those sites. Furthermore, the results of $\mathrm{Pr} / \mathrm{Ph}$ ratios $<1$ and $\mathrm{C}_{18} / \mathrm{Ph}$ ratios $>1$ in almost all samples indicate that petroleum hydrocarbons from oil contamination have a widespread occurrence in the study area. Besides the chromatographically resolved compounds, an UCM of branched and cyclic hydrocarbons was observed in the range $C_{25}-C_{35}$ with a very prominent hump in the GC profile (Fig. 4). The source of the UCM can be confirmed to be due to the petroleum input by the presence of the biomarkers (hopanes and steranes) discussed below. The UCM had a maximum concentration of $53.8 \mu \mathrm{g} / \mathrm{g}$ for site 63 , followed by site $94(19.1 \mu \mathrm{g} / \mathrm{g})$. In addition, higher levels of UCM $(10 \mu \mathrm{g} / \mathrm{g})$ were also found in sites number 49,59, 76,77 and 78 . The ratios of UCM to resolved $C_{25}-C_{35} n$-alkanes $(U / A)$ vary from $<0.1$ to 0.9 (excluding sites 63 and 94). These $U / A$ ratios are below the criterion of petroleum contamination $(U / A>4)$ proposed by Maioli et al.(2011), indicating that petroleum contamination appeared at relatively low or moderate level in the LRD, except at few sites (63 and 94) in this delta. This was mainly due to the high stock of soil OM derived from higher plants in this area.

\subsection{Petroleum biomarkers}

The results presented above indicated that the contribution of hydrocarbons from the higher plant-derived OM was dominant in the LRD soils. However, the contribution from regional oil spills to the soil OM cannot be ignored. More definitive confirmation of oil pollution can be obtained by characteristic compounds which are unique to petroleum, such as hopanes and steranes (Tolosa et al., 2004; Hu et al., 2011). Due to their thermodynamic stability and source specificity, hopanes and steranes can provide a precise differentiation in the analyses of sources and fate of petroleum in the environment compared to aliphatic hydrocarbons. In this study, hopane and sterane series, the petroleum biomarker, were qualitatively detected in samples from all sites. Typical distributions of hopanes and steranes are shown in Fig. 5. It was found that the $m / z=191$ mass fragmentogram exhibited a series of $17 \alpha(\mathrm{H})$, $21 \beta(\mathrm{H})$-compounds $\left(\mathrm{C}_{29}-\mathrm{C}_{33}\right)$, and they were characterized by the maximizing at the $\mathrm{C}_{30}$ homologue. The $17 \beta(\mathrm{H})-21 \alpha(\mathrm{H})$ compounds were only detected with $C_{29}$ and $C_{30}$ homologues. Generally, the $17 \alpha(\mathrm{H})-21 \beta(\mathrm{H})$ structure, formed from the original $17 \beta(\mathrm{H})-$ $21 \alpha(\mathrm{H})$ structure that is unstable in sediments/soils, is an indicator of long-term microbial degradation processes (Peters and Moldowan,1993). The wide detections and high concentrations of $17 \alpha(\mathrm{H})-21 \beta(\mathrm{H})$ compared with $17 \beta(\mathrm{H})-21 \alpha(\mathrm{H})$ in this study suggest that there is a significant contribution of crude oil to the hydrocarbons in the LRD. In addition, $C_{31}, C_{32}$ and $C_{33}$ hopanes were characterized by the pairs of the $\mathrm{C}_{22}$-diastereoisomers $(22 \mathrm{R}$, $22 S)$. The $22 S /(22 S+22 R)\left(C_{31}-C_{33}\right)$ hopane ratios ranged between 0.54 and 0.65 in this work, close to the equilibrium value of full maturity at 0.6 (Tolosa et al., 2004). The $T_{\mathrm{s}} /\left(T_{\mathrm{s}}+T_{\mathrm{m}}\right)$ ratio ( $T_{\mathrm{s}}=18 \alpha-22,29,30$-trisnorhopane, $\quad T_{\mathrm{m}}=17 \alpha-22,29,30$-trisnorhopane) is also one of the most characteristic proxies for petroleum hydrocarbons (Tolosa et al., 2004). In this study, the ratios of $T_{\mathrm{s}}$ / $\left(T_{\mathrm{s}}+T_{\mathrm{m}}\right)$ for site 78 and 94 are $\sim 0.6$, confirming the presence of mature petroleum in the soils (Hostettler et al., 1999; Hu et al., 2011).

Similarly, the presence and composition of steranes in soils/sediments are also a useful biomarker for petroleum hydrocarbon. In this study, the pattern of steranes showed an occurrence of $5 \alpha, 14 \beta, 17 \beta$ and $5 \alpha, 14 \alpha, 17 \alpha$ configurations, both occurring as $20 S$ and 20R epimers in $C_{27}-C_{29}$ homologues, indicating an important contribution of the petroleum residues (Aboul-Kassim and Sim- 

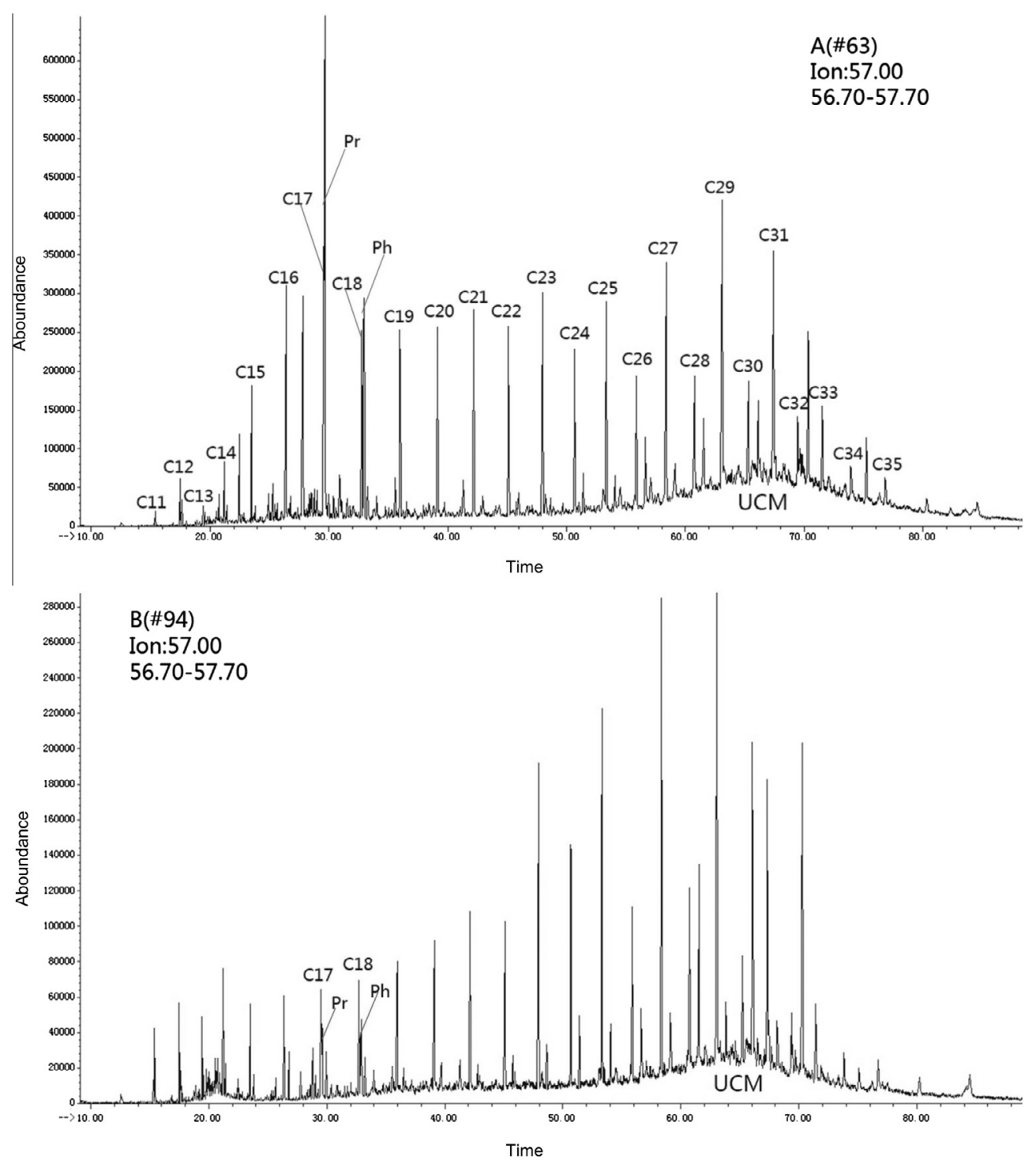

Fig. 4. Aliphatic hydrocarbon profile (included UCM) of typical soil samples at sites of 63(A) and 94(B).

oneit, 1996). In addition, the ratio of sterane isomerization $S /(S+R)$ reflects the different level of thermal maturity. The values of $\alpha \alpha \alpha C_{29}$ sterane $S /(S+R)$ ratios in the soils are 0.46 for site 78 and 0.57 for site 94 , respectively, close to the equilibrium value of 0.55 , suggesting the presence of full mature petroleum constituents (Aboul-Kassim and Simoneit, 1996). Furthermore, the $C_{29}$ sterane is probably derived from higher plant resin, while the abundance of $\mathrm{C}_{27}$ sterane is indicative of main contribution from microbial organism. The predominance of $C_{27}$ over $C_{28}$ and $C_{29}$ steranes suggests a marine origin for the petroleum products contaminate the sediments (Gao and Chen, 2008; Hu et al., 2011). Differently, the relative abundance of the three regular sterane series are in the order of $C_{29}>C_{28}>C_{27}$ in this study, suggesting that the soils were contaminated by lacustrine-derived crude oil (Song et al., 2005; Hu et al., 2009) (Fig. 5). Other evidence of lacustrinederived crude oil input was the presence of gammacerane in the soil samples from sites 78 and 94 . Gammacerane, as a lacustrine biomarker, is commonly found in most Chinese crude oil and is also present in several soil and sediment samples (Fu and Sheng, 1989).

Alkylated PAHs are widely detected in oil products which are usually produced or released during the diagenetic processes. Total alkylated PAHs vary from 0.05 to $4.99 \mu \mathrm{g} / \mathrm{g}$. Higher levels of total alkylated PAHs ( $>1 \mu \mathrm{g} / \mathrm{g}$ ) were found in sites number 36 , $59,76,77,78$ and 94 . In this study, there were strong correlations between the individual alkylated PAH (alkylated naphthalen (Nap), alkylated fluorene (Fl), alkylated phenanthren (Phe), alkylated pyrene (Pyr) and alkylated chrysene (Chr)) concentrations (Fig. 6A-C). In contrast, the concentrations of parent Phe were not correlated with alkylated Phe, suggesting that they were derived from different sources (Fig. 6D). In general, the incomplete combustion of $\mathrm{OM}$ is known to be the primary source of parent $\mathrm{PAHs}$ in the environment, while the degradation process of $\mathrm{OM}$ favors the formation of alkylated PAHs (Mai et al., 2001; Yunker et al., 2002a; Neşer et al., 2012). Our results indicated that the alkylated compounds in the LRD had a different source with pyrogenic one. A plausible explanation for this observation is that the oil-related source is prevalent for the alkylated compounds (Mai et al., 2001; Zakaria et al., 2002). In addition, values of methylphenanthrene (MP)/Phe ratio $>1$ are indicative of a petrogenic source, while MP/Phe ratios $<1$ indicate a pyrogenic source (Yunker and Macdonald, 2003; Walker et al., 2005). The highest alkylated PAHs concentrations were found at sites number 76, 78 and 94 , in concert with high MP/Phe ratios $>1$ at these sites. This indicates a high petroleum contribution to the OM pool in the wetland soil in these areas (Table 2). 

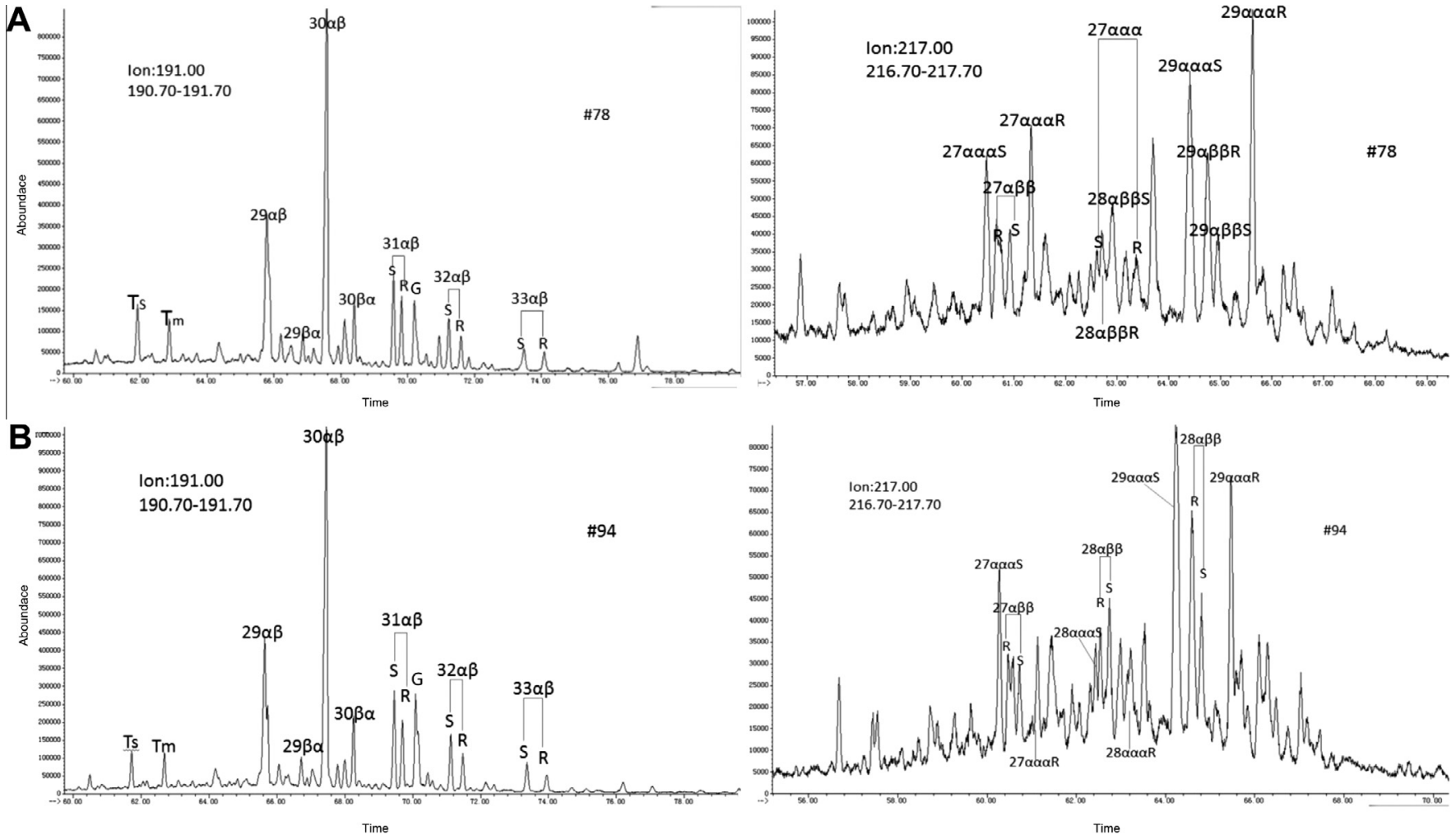

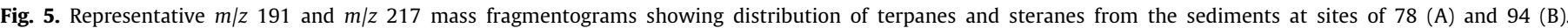
$\mathrm{G}=$ Gammacerane; $T_{\mathrm{s}}=18 \alpha(\mathrm{H})-22,29$, 30-trisnorhopane; $T_{\mathrm{m}}=17 \alpha(\mathrm{H})-22,29$, 30-trisnorhopane.
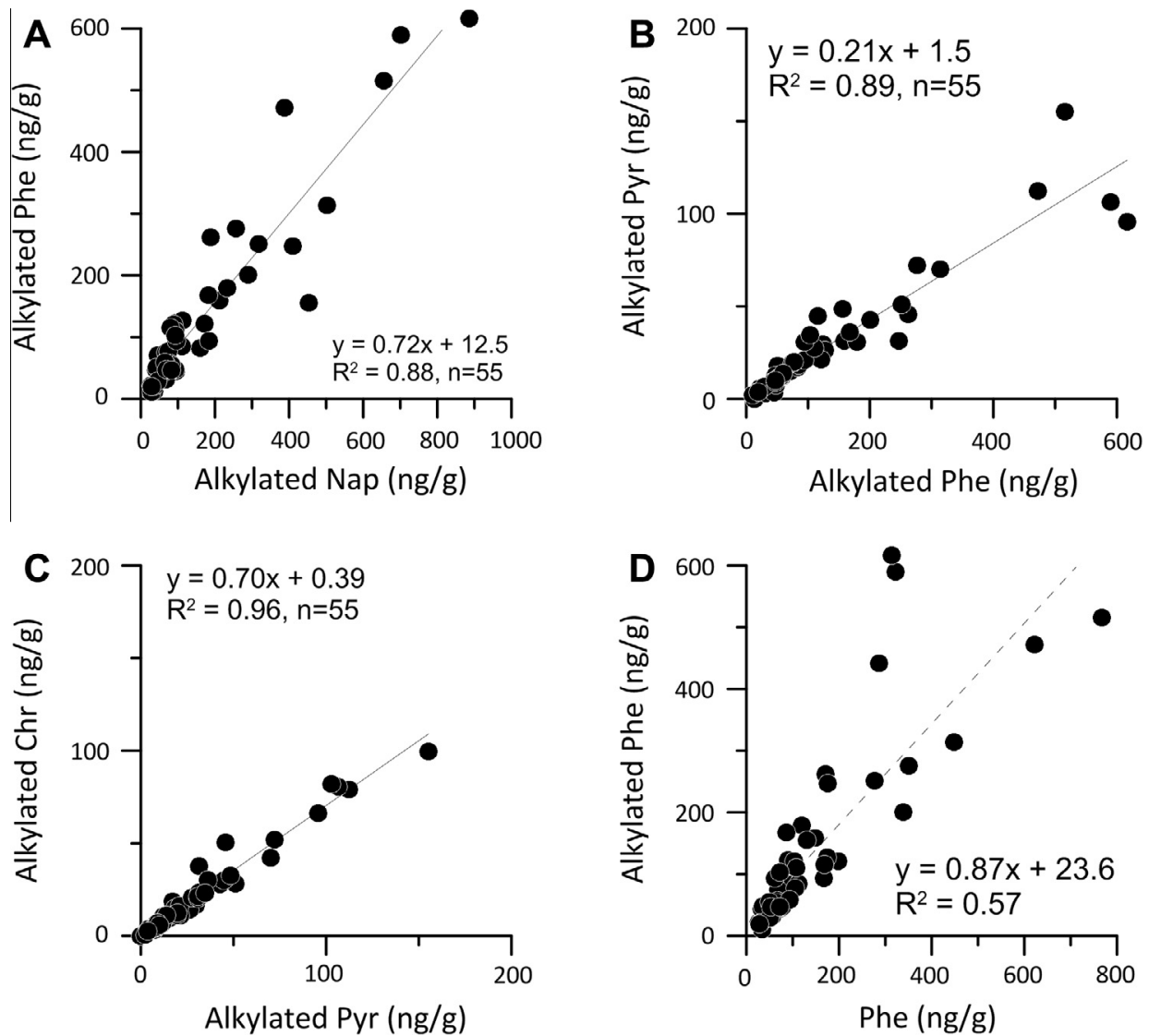

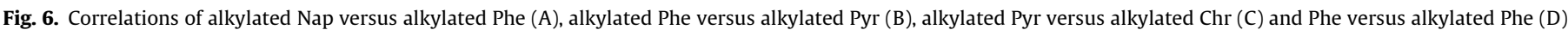


Table 2

Ratios of selected lipids for source identification in the soils from the Wetlands of the Liaohe Delta.

\begin{tabular}{|c|c|c|c|c|c|c|c|c|}
\hline & $L / S$ & CPI & $\mathrm{Pr} / \mathrm{Ph}$ & $\mathrm{C} 18 / \mathrm{Ph}$ & $\mathrm{UCM} / n$-alkanes & MP/PHE & TOC/TN & $\mathrm{HP} /(\mathrm{HP}+\mathrm{P})$ \\
\hline 27 & 2.8 & 3.9 & 0.4 & 2.5 & 0.9 & 0.6 & 33.4 & 49.4 \\
\hline 33 & 20.3 & 7.5 & 0.6 & 2.6 & 0.7 & 0.9 & 36.3 & 58.9 \\
\hline 34 & 10.4 & 4.4 & 0.4 & 2.7 & 0.1 & 0.4 & 37.0 & 86.9 \\
\hline 35 & 22.1 & 5.2 & 0.9 & 5.1 & 0.1 & 0.6 & 18.8 & 86.6 \\
\hline 36 & 12.4 & 5.1 & 0.4 & 6.4 & 0.2 & 0.7 & 20.4 & 82.5 \\
\hline 45 & 7.4 & 9.5 & 0.6 & 2.4 & 0.1 & 0.9 & 20.2 & 89.1 \\
\hline 46 & 5.6 & 9.7 & 0.5 & 1.8 & 0.3 & 0.6 & 19.4 & 78.0 \\
\hline 47 & 10.0 & 6.4 & 0.3 & 2.0 & 0.7 & 0.8 & 19.3 & 58.6 \\
\hline 48 & 8.4 & 7.6 & 0.2 & 1.7 & 0.4 & 1.4 & 20.4 & 67.6 \\
\hline 49 & 55.0 & 6.4 & 0.4 & 3.3 & 0.2 & 0.8 & 17.6 & 84.1 \\
\hline 50 & 9.7 & 5.7 & 0.5 & 4.0 & 0.2 & 0.6 & 26.2 & 77.7 \\
\hline 51 & 20.0 & 8.6 & 0.4 & 3.2 & 0.3 & 0.9 & 27.4 & 76.9 \\
\hline 52 & 7.7 & 6.8 & 0.2 & 1.4 & 0.6 & 0.8 & 34.5 & 60.1 \\
\hline 55 & 15.3 & 7.8 & 0.7 & 3.0 & 0.3 & 1.5 & 17.3 & 73.5 \\
\hline 56 & 12.3 & 4.6 & 0.6 & 6.2 & 0.2 & 1.4 & 32.5 & 79.4 \\
\hline 57 & 14.2 & 4.4 & 0.5 & 3.2 & 0.6 & 0.7 & 18.3 & 61.5 \\
\hline 58 & 19.6 & 4.7 & 0.5 & 4.6 & 0.3 & 0.7 & 24.7 & 75.5 \\
\hline 59 & 25.8 & 5.1 & 0.6 & 4.0 & 0.2 & 0.8 & 19.8 & 81.0 \\
\hline 60 & 17.5 & 6.6 & 0.4 & 3.0 & 0.3 & 0.9 & 35.9 & 78.1 \\
\hline 63 & 1.4 & 2.0 & 0.9 & 5.9 & 4.9 & 0.9 & 26.0 & 17.0 \\
\hline 74 & 10.0 & 5.9 & 0.4 & 3.8 & 0.3 & 1.2 & 24.0 & 74.4 \\
\hline 75 & 10.5 & 4.3 & 0.8 & 4.8 & 0.5 & 0.8 & 24.1 & 65.0 \\
\hline 76 & 6.4 & 3.7 & 0.8 & 5.1 & 0.8 & 1.8 & 21.3 & 52.7 \\
\hline 77 & 16.5 & 5.7 & 0.9 & 1.5 & 0.3 & 0.7 & 20.1 & 77.3 \\
\hline 78 & 2.2 & 4.2 & 0.7 & 5.4 & 0.4 & 1.9 & 17.9 & 63.9 \\
\hline 79 & 6.9 & 4.5 & 0.6 & 2.6 & 0.5 & 0.6 & 26.8 & 66.4 \\
\hline 80 & 10.1 & 6.5 & 0.4 & 2.6 & 0.4 & 0.8 & 36.2 & 68.3 \\
\hline 81 & 13.6 & 6.1 & 0.3 & 3.0 & 0.3 & 0.6 & 38.4 & 75.5 \\
\hline 82 & 18.7 & 6.6 & 0.5 & 2.7 & 0.3 & 1.1 & 30.9 & 73.2 \\
\hline 92 & 19.9 & 9.7 & 1.0 & 3.9 & 0.4 & 1.4 & 24.4 & 71.7 \\
\hline 93 & 4.1 & 4.5 & 1.0 & 4.8 & 0.5 & 2.0 & 27.1 & 57.3 \\
\hline 94 & 5.2 & 2.5 & 0.4 & 0.9 & 2.8 & 1.4 & 28.1 & 25.8 \\
\hline 95 & 26.9 & 4.3 & 0.6 & 4.9 & 0.3 & 1.0 & 24.9 & 77.5 \\
\hline 96 & 20.9 & 6.4 & 0.5 & 5.5 & 0.1 & 0.7 & 25.0 & 86.6 \\
\hline 97 & 24.0 & 6.0 & 0.4 & 2.0 & 0.2 & 0.7 & 39.4 & 84.6 \\
\hline 98 & 3.5 & 5.8 & 0.6 & 4.1 & 0.2 & 0.3 & 33.1 & 82.8 \\
\hline 99 & 8.5 & 7.5 & 0.5 & 3.1 & 0.2 & 0.8 & 30.5 & 83.9 \\
\hline 100 & 13.8 & 6.6 & 0.4 & 2.6 & 0.4 & 0.9 & 27.7 & 70.6 \\
\hline 101 & 6.2 & 6.2 & 0.9 & 3.7 & 0.6 & 1.1 & 27.7 & 58.5 \\
\hline 113 & 10.0 & 6.1 & 0.9 & 3.8 & 0.3 & 1.5 & 27.9 & 76.9 \\
\hline 114 & 15.0 & 6.6 & 1.0 & 5.3 & 0.2 & 0.9 & 27.1 & 82.5 \\
\hline 115 & 11.1 & 6.5 & 0.6 & 3.1 & 0.4 & 0.9 & 30.6 & 71.7 \\
\hline 118 & 8.0 & 7.2 & 0.3 & 4.1 & 0.2 & 0.7 & 36.3 & 79.9 \\
\hline 119 & 18.1 & 6.6 & 0.2 & 2.1 & 0.2 & 0.7 & 26.7 & 82.0 \\
\hline 130 & 9.4 & 4.9 & 0.9 & 3.8 & 0.3 & 1.2 & 36.7 & 70.9 \\
\hline 131 & 7.0 & 5.2 & 0.8 & 3.8 & 0.3 & 0.8 & 37.6 & 73.1 \\
\hline 132 & 18.1 & 4.5 & 1.0 & 1.3 & 0.9 & 1.1 & 42.7 & 51.3 \\
\hline 133 & 14.6 & 5.0 & 0.9 & 5.1 & 0.2 & 0.6 & 25.9 & 83.1 \\
\hline 135 & 30.7 & 6.2 & 0.3 & 2.1 & 0.3 & 0.6 & 26.3 & 74.0 \\
\hline 136 & 11.1 & 5.4 & 0.6 & 2.9 & 0.4 & 0.9 & 31.4 & 69.2 \\
\hline 145 & 2.4 & 5.3 & 0.6 & 2.4 & 0.5 & 0.7 & 43.4 & 62.7 \\
\hline 156 & 7.4 & 5.8 & 0.4 & 2.1 & 0.4 & 0.7 & 26.7 & 71.0 \\
\hline 201 & 14.0 & 1.5 & 1.0 & 2.4 & 0.2 & 1.9 & 34.7 & 79.8 \\
\hline 204 & 9.3 & 5.3 & 0.9 & 2.9 & 0.5 & 1.5 & 43.2 & 66.5 \\
\hline 207 & 14.7 & 5.5 & 0.9 & 2.0 & 0.3 & 1.4 & 40.9 & 72.0 \\
\hline
\end{tabular}

$L / S: \sum C_{21+} / \sum C_{20-}$ for $n$-alkanes.

CPI: $\left(C_{21}+C_{23}+C_{25}+C_{27}+C_{29}+C_{31}+C_{33}\right) /\left(C_{22}+C_{24}+C_{26}+C_{28}+C_{30}+C_{32}+C_{34}\right)$

$\mathrm{UCM} / n$-alkanes: $\mathrm{UCM} / \mathrm{C}_{25}-\mathrm{C}_{35} n$-alkanes.

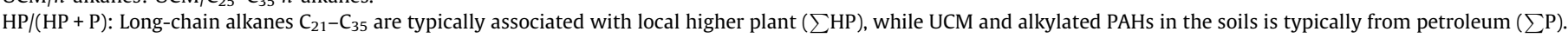

\subsection{Natural and petroleum contributions to hydrocarbons in $\mathrm{OM}$}

The prevalence of odd over even carbon number of the longchain $n$-alkanes at most sites can be used to identify higher plants as the predominant natural source of $\mathrm{OM}$ in the wetland soils of the LRD. Similarly, the UCM, hopanes, steranes and alkylated PAHs can be used to identify the contribution from petroleum hydrocarbons. Using this classification, we could assess the relative contributions of natural source (higher plants) and petroleum hydrocarbons as sources of the OM in the delta soils (Table 2). The results clearly indicated that the main origin of the soil OM in the study area was from natural sources, namely higher plants ( $72 \pm 15 \%$ ), except at sites 63 and 94 , where the natural hydrocarbons only contributed $21 \%$ and $31 \%$ to the total hydrocarbons, respectively. This indicated that there was a relative higher contribution derived from petroleum hydrocarbons at these two sites. As far as the soil samples with the highest TOC contents concerned (sites number $35,36,49,59,76,77$ and 78), the high levels of petroleum-derived hydrocarbons were also detected in sites number $49,59,76,77$ and 78 , suggesting a possible heavy petroleum contamination in this area. It was interesting to note that the high level of petroleum hydrocarbons was accompanied with high in- 
puts of natural hydrocarbons in several sites, such as sites number 49, 59, 76, 77 and 78, which were located in high-productivity Phragmites wetlands. Thus, the high TOC contents in these sites were likely caused by a combination of natural accumulation of high plant-derived OM because of the wet and anoxic soil conditions, and contamination by petrochemicals from the oil industry. The spatial distributions of the TOC and the source characteristic in the LRD were consistent with the actual field survey. This suggests that the $P$. australis-vegetated wetlands have strong potentials for the preservation of organic carbon in the wetlands.

\section{Conclusions}

This work showed that the wetland soil OM in the LRD was primarily derived from higher plants. The highest hydrocarbon inputs from both higher plants and petroleum contamination were detected in soils vegetated by Phragmites australis, which had significantly higher contents of TOC than soils from other types of vegetation. This suggests that $P$. australis-covered soils have a strong ability for the production and preservation of $\mathrm{OM}$ in the region. In contrast, the reclaimed agricultural soils vegetated with Oryza sativa and Zea mays had lower TOC contents compared to the soils of the natural wetlands vegetated by Phragmites australis and Suaeda salsa. This implies that the reclamation of the delta wetlands for agricultural production could reduce the soil's potential for the OM preservation. Furthermore, our study shows that there is a ubiquitous presence of petroleum contamination in the LRD.

\section{Acknowledgements}

This work was jointly funded by the Ministry of Land and Resources program: "Special foundation for scientific research on public causes" (Grant No. 201111023), Marine Safeguard Project (Grant No. GZH201200503), and the China Geological Survey (Grant No. 1212010611402).

\section{References}

Aboul-Kassim, T.A.T., Simoneit, B.R.T., 1996. Lipid geochemistry of surficial sediments from the coastal environment of Egypt I. Aliphatic hydrocarbons characterization and sources. Marine Chemistry 54 (1-2), 135-158.

Aravena, R., Evans, M.L., Cherry, J.A., 1993. Stable isotopes of oxygen and nitrogen in source identification of nitrate from septic systems. Ground Water 31 (2), 180186.

Bourbonniere, R.A., Meyers, P.A., 1996. Sedimentary geolipid records of historical changes in the watersheds and productivities of Lakes Ontario and Erie. Limnology and Oceanography 41 (2), 352-359.

Bridgham, S.D., Megonigal, J.P., Keller, J.K., Bliss, N.B., Trettin, C., 2006. The carbon balance of North American wetlands. Wetlands 26 (4), 889-916.

Fu, J.M., Sheng, G.Y., 1989. Biological composition of typical source rocks and related oils of terrestrial origin in the People's Republic of China, a review. Applied Geochemistry 4 (1), 13-22.

Gao, X., Chen, S., 2008. Petroleum pollution in surface sediments of Daya Bay, South China, revealed by chemical fingerprinting of aliphatic and alicyclic hydrocarbons. Estuarine, Coastal and Shelf Science 80 (1), 95-102.

Guo, W., He, M.C., Yang, Z.F., Lin, C.Y., Quan, X.C., Wang, H.Z., 2007. Distribution of polycyclic aromatic hydrocarbons in water, suspended particulate matter and sediment from Daliao River watershed, China. Chemosphere 68 (1), 93-104.

Ji, G.D., Sun, T.H., Zhou, Q.X., Sui, X., Chang, S.J., Li, P.J., 2002. Constructed subsurface flow wetland for treating heavy oil-produced water of the Liaohe Oilfield in China. Ecological Engineering 18 (4), 459-465.

Hostettler, F.D., Pereira, W.E., Kvenvolden, K.A., van Geen, A., Luoma, S.N., Fuller, C.C., Anima, R., 1999. A record of hydrocarbon input to San Francisco Bay as traced by biomarker profiles in surface sediment and sediment cores. Marine Chemistry 64 (1-2), 115-127.

Hu, L.M., Guo, Z.G., Feng, J.L., Yang, Z.S., Fang, M., 2009. Distributions and sources of bulk organic matter and aliphatic hydrocarbons in surface sediments of the Bohai Sea, China. Marine Chemistry 113 (3-4), 197-211.

Hu, L., Guo, Z., Shi, X., Qin, Y., Lei, K., Zhang, G., 2011. Temporal trends of aliphatic and polyaromatic hydrocarbons in the Bohai Sea, China: evidence from the sedimentary record. Organic Geochemistry 42 (10), 1181-1193.
Kimbrough, K.L., Dickhut, R.M., 2006. Assessment of polycyclic aromatic hydrocarbon input to urban wetlands in relation to adjacent land use. Marine Pollution Bulletin 52 (11), 1355-1363.

Lawrence, M., 1994. Surface area control of organic carbon accumulation in continental shelf sediments. Geochimica et Cosmochimica Acta 58 (4), 12711284.

Logan, G.A., Eglinton, G., 1994. Biogeochemistry of the Miocene lacustrine deposit at Clarkia, Northern Idaho, USA. Organic Geochemistry 21 (8-9), 857-870.

Mai, B.X., Fu, J.M., Zhang, G., Lin, Z., Min, Y.S., Sheng, G.Y., Wang, X.M., 2001. Polycyclic aromatic hydrocarbons in sediments from the Pearl River and estuary, China: spatial and temporal distribution and sources. Applied Geochemistry 16 (11-12), 1429-1445.

Maioli, O.L.G., Rodrigues, K.C., Knoppers, B.A., Azevedo, D.A., 2011. Distribution and sources of aliphatic and polycyclic aromatic hydrocarbons in suspended particulate matter in water from two Brazilian estuarine systems. Continental Shelf Research 31 (10), 1116-1127.

Medeiros, P.M., Bícego, M.C., Castelao, R.M., Del Rosso, C., Fillmann, G., Zamboni, A.J., 2005. Natural and anthropogenic hydrocarbon inputs to sediments of Patos Lagoon Estuary, Brazil. Environment International 31 (1), 77-87.

Medeiros, P.M., Bicego, M.C., 2004a. Investigation of natural and anthropogenic hydrocarbon inputs in sediments using geochemical markers. I. Santos, SPBrazil. Marine Pollution Bulletin 49 (11-12), 761-769.

Medeiros, P.M., Bicego, M.C., 2004b. Investigation of natural and anthropogenic hydrocarbon inputs in sediments using geochemical markers. II. São Sebastião, SP-Brazil. Marine Pollution Bulletin 49 (11-12), 892-899.

Meyers, P.A., Ishiwatari, R., 1993. Lacustrine organic geochemistry-an overview of indicators of organic matter sources and diagenesis in lake sediments. Organic geochemistry 20 (7), 867-900.

Meyers, P.A., 1997. Organic geochemical proxies of paleoceanographic, paleolimnologic, and paleoclimatic processes. Organic Geochemistry 27 (5-6), 213-250.

Mille, G., Asia, L., Guiliano, M., Malleret, L., Doumenq, P., 2007. Hydrocarbons in coastal sediments from the Mediterranean Sea (Gulf of Fos area, France). Marine Pollution Bulletin 54 (5), 566-575.

Mitsch, W.J., Bernal, B., Nahlik, A.M., Mander, Ü., Zhang, L., Anderson, C.J., Jørgensen, S.E., Brix, H., 2012. Wetlands, carbon, and climate change. Landscape Ecology 115.

Mitsch, W.J., Gosselink, J.G., 2007. Wetlands, fourth ed. John Wiley \& Sons, Inc., New Jersey, p. 582.

Neşer, G., Kontas, A., Ünsalan, D., Altay, O., Darılmaz, E., Uluturhan, E., Küçüksezgin, F., Tekoğul, N., Yercan, F., 2012. Polycyclic aromatic and aliphatic hydrocarbons pollution at the coast of Aliağa (Turkey) ship recycling zone. Marine Pollution Bulletin 64 (5), 1055-1059.

Peters, K.E., Moldowan, J.M., 1993. The Biomarker Guide: Interpreting Molecular Fossils in Petroleum. Prentice-Hall Inc., Englewood Cliffs, NJ.

Roulet, N.T., 2000. Peatlands, carbon storage, greenhouse gases, and the Kyoto protocol: prospects and significance for Canada. Wetlands 20 (4), 605-615.

Schefuß, E., Ratmeyer, V., Stuut, J.B.W., Jansen, J.H.F., Sinninghe Damsté, J.S., 2003. Carbon isotope analyses of $n$-alkanes in dust from the lower atmosphere over the Central Eastern Atlantic. Geochimica et Cosmochimica Acta 67 (10), 17571767.

Song, Z., You, M., Duzgoren-Aydin, N.S., 2005. Characterization of particulate organics accumulated on the ceiling of vehicular tunnels in Hong Kong and Guangzhou, China. Atmospheric Environment 39 (34), 6398-6408.

Tanner, B.R., Uhle, M.E., Mora, C.I., Kelley, J.T., Schuneman, P.J., Lane, C.S., Allen, E.S. 2010. Comparison of bulk and compound-specific $\delta 13 \mathrm{C}$ analyses and determination of carbon sources to salt marsh sediments using n-alkane distributions (Maine, USA). Estuarine, Coastal and Shelf Science 86 (2), 283291.

Tolosa, I., de Mora, S., Sheikholeslami, M.R., Villeneuve, J.P., Bartocci, J., Cattini, C., 2004. Aliphatic and aromatic hydrocarbons in coastal caspian Sea sediments. Marine Pollution Bulletin 48 (1-2), 44-60.

Tolosa, I., Mesa-Albernas, M., Alonso-Hernandez, C.M., 2009. Inputs and sources of hydrocarbons in sediments from Cienfuegos bay, Cuba. Marine Pollution Bulletin 58 (11), 1624-1634.

Walker, S.E., Dickhut, R.M., Chisholm-Brause, C., Sylva, S., Reddy, C.M., 2005. Molecular and isotopic identification of PAH sources in a highly industrialized urban estuary. Organic Geochemistry 36 (4), 619-632.

Wang, C., Wang, W., He, S., Du, J., Sun, Z., 2011. Sources and distribution of aliphatic and polycyclic aromatic hydrocarbons in Yellow River Delta Nature Reserve, China. Applied Geochemistry 26 (8), 1330-1336.

Wang, G., Lu, Y., Han, J., Luo, W., Shi, Y., Wang, T., Sun, Y., 2010. Hexachlorobenzene sources, levels and human exposure in the environment of China. Environment International $36(1), 122-130$.

Wang, X.C., Chen, R.F., Berry, A., 2003. Sources and preservation of organic matter in Plum Island salt marsh sediments (MA, USA): long-chain $n$-alkanes and stable carbon isotope compositions. Estuarine, Coastal and Shelf Science 58 (4), $917-$ 928.

Wang, X.C., Sun, S., Ma, H.Q., Liu, Y., 2006. Sources and distribution of aliphatic and polyaromatic hydrocarbons in sediments of Jiaozhou Bay, Qingdao, China. Marine Pollution Bulletin 52 (2), 129-138.

Xu, B., Yang, X., Gu, Z., Zhang, Y., Chen, Y., Lv, Y., 2009. The trend and extent of heavy metal accumulation over last one hundred years in the Liaodong Bay, China. Chemosphere 75 (4), 442-446.

Yunker, M.B., Macdonald, R.W., Vingarzan, R., Mitchell, R.H., Goyette, D., Sylvestre, S., 2002a. PAHs in the Fraser River basin: a critical appraisal of PAH ratios as 
indicators of PAH source and composition. Organic Geochemistry 33 (4), 489515.

Yunker, M.B., Backus, S.M., Graf Pannatier, E., Jeffries, D.S., Macdonald, R.W., 2002b. Sources and significance of alkane and PAH hydrocarbons in Canadian Arctic Rivers. Estuarine, Coastal and Shelf Science 55 (1), 1-31.

Yunker, M.B., Macdonald, R.W., 2003. Petroleum biomarker sources in suspended particulate matter and sediments from the Fraser River Basin and Strait of Georgia, Canada. Organic Geochemistry 34 (10), 1525-1541.
Zaghden, H., Kallel, M., Elleuch, B., Oudot, J., Saliot, A., 2007. Sources and distribution of aliphatic and polyaromatic hydrocarbons in sediments of $S_{\mathrm{fax}}$, Tunisia, Mediterranean Sea. Marine Chemistry 105 (1-2), 70-89.

Zakaria, M.P., Takada, H., Tsutsumi, S., Ohno, K., Yamada, J., Kouno, E., Kumata, H., 2002. Distribution of Polycyclic Aromatic Hydrocarbons (PAHs) in rivers and estuaries in Malaysia: a widespread input of petrogenic PAHs. Environmental Science and Technology 36 (9), 1907-1918. 